\title{
Scholarly Literature from Selected Universities of Delhi and Uttar Pradesh: A Pilot Study
}

\author{
Bhaskar Mukherjee, \\ Lecturer, Department of Library and Information Science, \\ Banaras Hindu University, Varanasi, U.P. INDIA. \\ Email: mukherjee.bhaskar@gmail.com
}

\begin{abstract}
This study presents the publications output of the four most productive Indian academic institutions in the mainstream scientific literature for the eight-year-period 2000-2007. This paper discusses the distribution of publications by institution, type of publication, pattern of co-authorship, and citations. The results show that among the four universities, the authors of Delhi University contributed the highest number of articles, followed by Banaras Hindu University. There is also an increasing trend of collaborative research among Indian authors as well as more frequent collaboration with international authors. Biochemistry and molecular biology is one of the most prolific research areas in these four Indian universities. The average rate of references per item is 28 and the citations received per item are 3.56 .
\end{abstract}

Keywords: Scientific Research-India; University Productivity-India; Scholarly Literature-India.

\section{Introduction}

Historically, India has been one of the most prominent South Asian countries, owing to its global reputation for academic and research excellence. India has a large scientific establishment and publishes on average thirteen thousand research papers a year according to the Science Citation Index. The last few decades have witnessed a restructuring in scientific research in India. Modern information and communication technology (ICT) has acted as a catalyst in a paradigm shift in terms of quality and quantity of research. Now researchers in national institutions and universities in India have greater access to research literature due to subscriptions to many e-journals and scholarly databases in most subject areas. Government research agencies have introduced research fellowship opportunities for pursuing research degrees in order to attract talented students into research and teaching professions in India and to reverse the brain-drain to developed countries. At the same time, however, there continues to be extensive discussion regarding the perceived deficit in quantity, and possibly in quality, of research at the university level. One optimistic view explains the reason as lack of funds while others blame the lack of infrastructure. It is, therefore, important that a study be undertaken with the sole purpose of identifying the quality and quantity of research activity of well-funded Indian universities.

\section{Objective and Scope of the Study}

The purpose of this pilot study is to explore the main scientific output in order to measure the extent of scientific development in India. Specific objectives of the paper include:

- to track the growth of publications from prominent Indian universities during 20002007.

- To explore the type of publications in which authors have preferred to publish their work.

- To determine the nature of collaborative research and the amount of international collaboration.

- To know the amount of inter-university collaborative research.

- To document the highly preferred journals and research subjects of published authors.

- To discover the countries and institutions most involved in research collaboration with Indian scholars and researchers; and 
- to compare the quality of research output in terms of the number of citations given and received

\section{Methodology}

The data presented in this paper have been accessed from Web of Science, published by the Institute for Scientific Information (ISI). Since the level of interest in this study was institutional rather than departmental or individual, a different approach than per full time equivalent (FTE) publication rate was developed. All papers contributed by the authors (either individually or in collaboration with authors from other organizations) from four central universities in India have been considered for the present study. The four Indian institutions studied are Aligarh Muslim University (AMU), Aligarh, U.P.; Banaras Hindu University (BHU), Varanasi, U.P.; Delhi University (DU), Delhi; and Jawaharlal Nehru University (JNU), New Delhi. It was possible to determine institutional counts for each of these universities by counting the times that faculty members' publications from each university were listed in the Science Citation Index, Social Science Citation Index (2001 to present), and Arts E Humanities Index (2001 to present) during 2000 to 2007. All these universities have a long history, and all offer a wide range of academic programs and subjects, which is not characteristic of other Indian universities.

The bibliographic details of the published literature were collected using the general search option of Web of Science. In the address field of the general search option, the name of the university or popular abbreviated name of the university (AMU or Aligarh Muslim Univ., BHU or Banaras Hindu Univ., DU or Delhi Univ. and JNU or Jawaharlal Nehru Univ.) were used. Additionally, in the publication year field, 2000-2007 was used in order to search literature published only during those years in the scholarly journals. After careful verification, only those records were selected that were contributed by the authors of these four universities either individually or in collaboration with others. All the searched results were then saved in a text file and imported into Microsoft Excel for analysis.

The performance of these four institutions were judged and compared on the basis of various quantitative indicators: (a) size of scientific activity measured by volume of production in various types of publications during the period of study, (b) authorship pattern and collaboration of scientific activity measured by co-authorship and the amount of national and international collaboration, and (c) impact of scientific activity measured by the numbers of citations given and citations received during the period of study. These bibliometric techniques constitute a relatively objective indicator for measuring discourse popularity (Ponzi \& Michael, 2003). According to the work of Abrahamson $(1991,1996)$ and Abrahamson \& Fairchild (1999), the bibliometric technique of article counting is a reliable approach to beginning an analysis of published literature in order to illuminate and trace the development of a concept.

Basic information about these four universities was collected from their official Web sites. Table 1 below presents this material. 
Table 1: Basic Information about the Universities

\begin{tabular}{|c|c|c|c|c|}
\hline $\begin{array}{c}\text { Name of the } \\
\text { Institution }\end{array}$ & $\begin{array}{c}\text { Year of } \\
\text { Establishment }\end{array}$ & $\begin{array}{c}\text { Schools/ } \\
\text { Faculty }\end{array}$ & Departments & $\begin{array}{c}\text { Faulty Members* } \\
\text { (approx) }\end{array}$ \\
\hline AMU & 1,866 & 12 Faculties & 71 & 1,111 \\
\hline BHU & 1,916 & $\begin{array}{c}\text { 14 Faculties, } \\
\text { 3 Institutes }\end{array}$ & 138 & 2,820 \\
\hline DU & 1,922 & 16 Faculties & 76 & 849 \\
\hline JNU & 1,969 & $\begin{array}{c}\text { 10 Schools } \\
\text { 04 Centers }\end{array}$ & - & 526 \\
\hline
\end{tabular}

* Excluding faculty members at the college level

\section{Results}

\section{Growth of Literature}

As indicated in Table 2, authors from these four universities have contributed as many as 10,281 publications during 2000 to 2007 in different scholarly journals. A steady growth in the number of total publications has been observed from 2000 to 2007. In 2000 (the starting year of the study), 979 articles were published. This number rose to 1,587 in 2006 , falling by one $(1,586)$ in 2007. From 2000 to 2006, the number of published articles increased by an average of 86 per year.

Table 2: Distribution of Articles by Year

\begin{tabular}{|c|c|c|c|c|c|}
\hline Year & AMU & BHU & DU & JNU & Total \\
\hline 2000 & 137 & 391 & 320 & 131 & 979 \\
\hline 2001 & 147 & 360 & 429 & 177 & 1,113 \\
\hline 2002 & 153 & 323 & 412 & 163 & 1,051 \\
\hline 2003 & 212 & 365 & 500 & 168 & 1,245 \\
\hline 2004 & 213 & 368 & 508 & 192 & 1,281 \\
\hline 2005 & 259 & 381 & 583 & 216 & 1,439 \\
\hline 2006 & 296 & 481 & 617 & 193 & 1,587 \\
\hline 2007 & 274 & 538 & 607 & 167 & 1,586 \\
\hline Total & $\mathbf{1 , 6 9 1}$ & $\mathbf{3 , 2 0 7}$ & $\mathbf{3 , 9 7 6}$ & $\mathbf{1 , 4 0 7}$ & $\mathbf{1 0 , 2 8 1}$ \\
\hline
\end{tabular}

Figure 1: Growth of Literature during 2000 to 2007

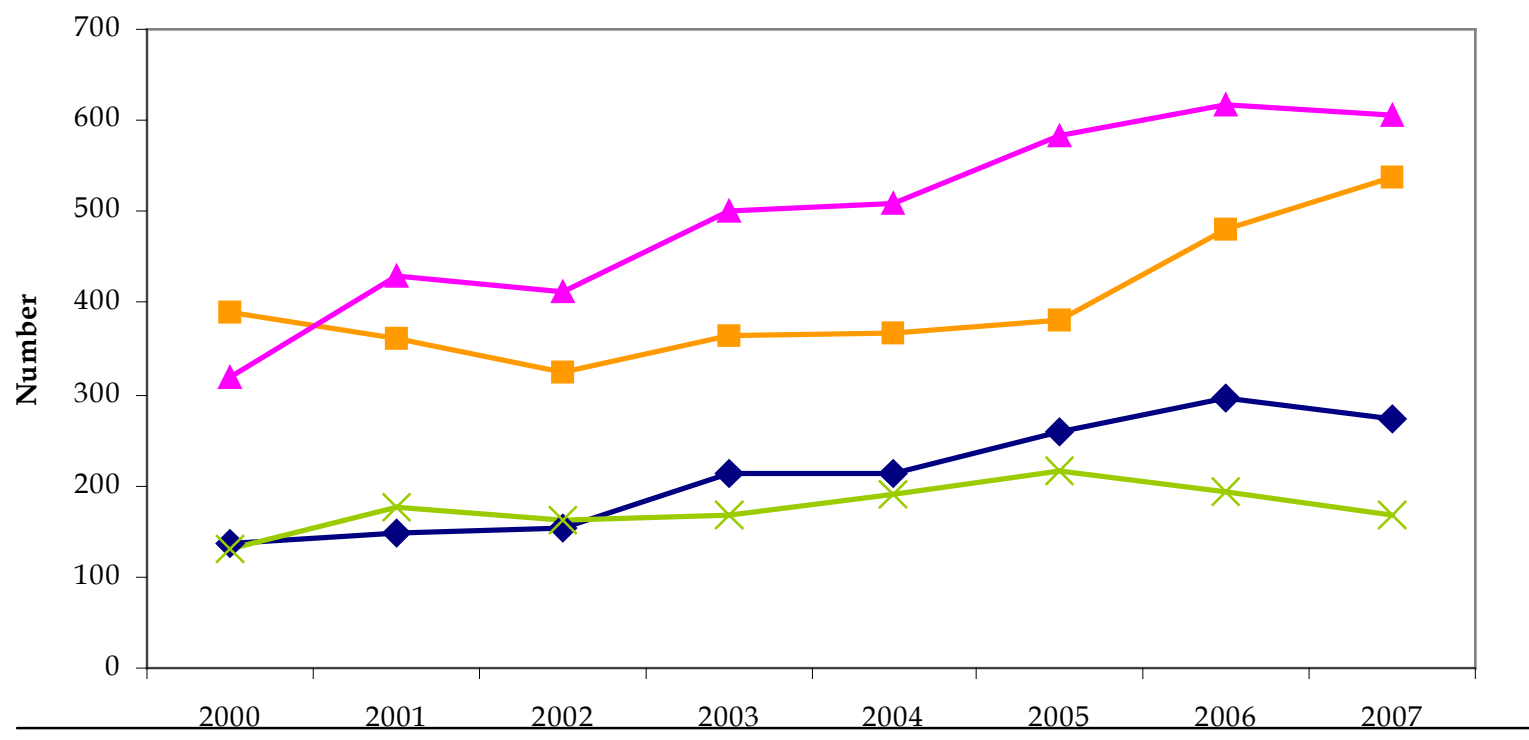


As evident from Figure 1, at the individual universities there is a gradual increase in publications from 2000-2006 with a nominal drop between 2001-2002 in the case of BHU, DU and JNU and between 2006-2007 in the case of AMU, DU, and JNU. The reasons for the slow growth rate between 2001/2002 and 2006/2007 are not known. Of the total 10,281 publications, the highest number of publications were contributed by authors from Delhi University $(3,976)$ followed by Banaras Hindu University (3,207), Aligarh Muslim University $(1,691)$, and Jawaharlal Nehru University $(1,407)$. The number of publications in the case of BHU and DU is very much higher than that of the other two universities. A possible explanation for this phenomenon is that BHU and DU have more faculty members (including faculty members from affiliated colleges) than AMU and JNU.

\section{Types of Publication}

Table 3 presents the distribution of published literature according to type. Of the 10,281 published papers, 9,180 (89.29\%) were periodical articles, followed by 264 (2.56\%) reviews and $238(2.31 \%)$ abstracts. That the highest number of publications was scholarly periodical articles indicates that the authors from these universities were involved enough in various meaningful research activities to be able to disseminate their research findings through scholarly journals.

Table 3: Type of Publications

\begin{tabular}{|l|c|c|c|c|c|}
\hline \multicolumn{1}{|c|}{ Year } & AMU & BHU & DU & JNU & Total \\
\hline Articles & 1,598 & 2,933 & 3,482 & 1,167 & 9,180 \\
\hline Biographical items & 0 & 8 & 10 & 2 & 20 \\
\hline Book Reviews & 3 & 5 & 140 & 80 & 228 \\
\hline Corrections & 9 & 12 & 15 & 7 & 43 \\
\hline Editorials & 15 & 47 & 38 & 31 & 131 \\
\hline Letters & 17 & 65 & 56 & 16 & 154 \\
\hline Meetings/Abstracts & 21 & 47 & 120 & 50 & 238 \\
\hline News Items & 0 & 6 & 2 & 13 & 21 \\
\hline Reviews & 28 & 84 & 111 & 41 & 264 \\
\hline Reprints & 0 & 0 & 1 & 0 & 1 \\
\hline Poetry & 0 & 0 & 1 & 0 & 1 \\
\hline Total & $\mathbf{1 , 6 9 1}$ & $\mathbf{3 , 2 0 7}$ & $\mathbf{3 , 9 7 6}$ & $\mathbf{1 , 4 0 7}$ & $\mathbf{1 0 , 2 8 1}$ \\
\hline
\end{tabular}

\section{Authorship Pattern}

As Harsanyi (1993) has shown, different disciplines interpret the order of authorship differently. Some list co-authors alphabetically; some list co-authors by the order of contribution to the article. There is at least one book for which the order of authorship was decided by a coin toss (Nye \& Keohane, 1972). There is also a reference to a practice in which the order of authorship was rotated within a group of researchers who published many articles and reports.

The last few decades have witnessed a growth in collaborative endeavors (Subramanyam, 1983). According to Qiu (1992), there is also a strong trend towards borrowing from and interpenetration across disciplines. The collaboration pattern of scientists working in these four Indian universities has been presented in Table 4. 
Table 4: Authorship Pattern

\begin{tabular}{|l|c|c|c|c|c|}
\hline \multirow{2}{*}{$\begin{array}{l}\text { Authors per } \\
\text { Article }\end{array}$} & \multicolumn{4}{|c|}{ Number of Articles } & \multirow{2}{*}{ Total } \\
\cline { 2 - 5 } & AMU & BHU & DU & JNU & \\
\hline Single author & 103 & 197 & 472 & 242 & 1,014 \\
\hline 2 authors & 529 & 998 & 897 & 348 & 2,772 \\
\hline 3 authors & 612 & 901 & 913 & 244 & 2,670 \\
\hline 4 authors & 244 & 498 & 592 & 219 & 1,553 \\
\hline 5 authors & 87 & 253 & 329 & 127 & 796 \\
\hline 6 authors & 39 & 129 & 185 & 66 & 419 \\
\hline 7 authors & 25 & 74 & 148 & 36 & 283 \\
\hline 8 authors & 14 & 27 & 75 & 19 & 135 \\
\hline 9 authors & 8 & 18 & 48 & 14 & 88 \\
\hline 10 authors & 4 & 8 & 30 & 6 & 48 \\
\hline$>10$ authors & 26 & 104 & 287 & 86 & 503 \\
\hline Total & $\mathbf{1 , 6 9 1}$ & $\mathbf{3 , 2 0 7}$ & $\mathbf{3 , 9 7 6}$ & $\mathbf{1 , 4 0 7}$ & $\mathbf{1 0 , 2 8 1}$ \\
\hline
\end{tabular}

Although the trend is toward multi-authorship, the majority of items published by these universities have two authors. The number of authors per item ranges mostly from one to twelve. In some cases, however, there are more than 500 authors in a single work. Most of these works were originated from corporate bodies. There were 169 items (105 from DU and 64 from BHU) published by corporate bodies. PHENIX Collaboration and DO Collaboration are two of the most prolific corporate bodies. Of the 10,281 items designated in this study, 1,014 articles $(9.82 \%)$ were by single authors. The number of articles written by two authors, three authors, and four authors were 2,772 (26.96\%), 2,670 (25.97) and 1,553 (15.10\%) respectively. The collaborative coefficient 0.90 indicates the trend of present research in these universities. At the individual university level, the highest number of the items from AMU and DU was contributed by three authors with two authors in the case of BHU and JNU.

If one considers the average publication rate by faculty members from these four universities, the present study indicates that the faculty members of DU have contributed the highest (4.68) number of articles followed by JNU (2.67), AMU (1.52), and BHU (1.13). It is essential to mention that the total number of faculty members in the present study (Table 1) includes only faculty members from university teaching departments. The total articles of an individual university as indexed in Web of Science, however, may include those authored by faculty members from affiliated colleges as well. For the purposes of this study, only publications listed under university headings were counted. Publications by faculty members from affiliated organizations of the same university or any other units at off-campus locations were studied separately.

There is a common perception that the first author is indeed primus inter pares. Either the first author has made the more significant contribution to the article or is the more senior member of the team. The minority view is that the order of authorship has little significance. From a practical point of view, it is true that most indexes list at least the first three authors of an article, but some reduce all but the first author to the status of et al. Web of Science, however, lists the names of all authors in the author's field. During investigation, it was found that at least one 
article in the dataset contained a list of 588 authors. The total number of authors in various positions (up to the fifth author) in an article is provided in Table 5.

Table 5: Authors' Position in an Article

\begin{tabular}{|c|c|c|c|c|c|c|}
\hline Universities & \multicolumn{7}{|c|}{ Authors' Position } \\
\cline { 2 - 7 } & $\begin{array}{c}\text { Single } \\
\text { Author }\end{array}$ & $\begin{array}{c}\text { 1st } \\
\text { Author }\end{array}$ & $\begin{array}{c}\text { 2nd } \\
\text { Author }\end{array}$ & $\begin{array}{c}\text { 3rd } \\
\text { Author }\end{array}$ & $\begin{array}{c}\text { 4th } \\
\text { Author }\end{array}$ & $\begin{array}{c}\text { 5th } \\
\text { Author }\end{array}$ \\
\hline AMU & $103(6.09)$ & 1,302 & 307 & 62 & 18 & 10 \\
\hline BHU & $208(6.48)$ & 2,168 & 744 & 211 & 45 & 24 \\
\hline DU & $479(12.04)$ & 2,242 & 1,038 & 282 & 82 & 29 \\
\hline JNU & $248(17.62)$ & 786 & 311 & 104 & 31 & 9 \\
\hline
\end{tabular}

Note: Position of all authors of an article measured. If both authors were from the same university, different position is mentioned for differen authors.

From the data in Table 5 it is evident that most of the authors from these universities preferred to contribute their work either as first or second author rather than any other position. Only 17.62 percent of the items from JNU, 12.04 percent of the items from DU, 6.48 percent of the items from BHU, and 6.09 percent of the items from AMU were reported as by a single author. This is a clear indication that team research is the most prevalent research process within these four universities of India. It is important to note, however, that most of these research teams consist of members of different national and international research organizations rather than faculty only from these four universities. It may be that inter-university research is not common among these universities. As indicated in Table 6, there are only 52 items reported that have been jointly contributed by authors from JNU and DU, 13 from DU and BHU, 7 from JNU and $\mathrm{BHU}$, four from BHU and AMU, two from DU and AMU, and one from AMU and JNU.

Table 6: Inter-university Research Activity among the Four Indian Universities

\begin{tabular}{|c|c|c|c|c|}
\hline & AMU & BHU & DU & JNU \\
\hline AMU & 89 & 4 & 2 & 1 \\
\hline BHU & 4 & 316 & 13 & 7 \\
\hline DU & 2 & 13 & 387 & 52 \\
\hline JNU & 1 & 7 & 52 & 103 \\
\hline
\end{tabular}

\section{Geographic Location of Collaborative Authors}

International scientific collaboration has been of increasing interest in recent years. This is due to the higher quality of collaborative papers as shown by higher average impacts when compared to solely national publications (Van Raan, 1998) and to the benefits gained by peripheral countries in being able to integrate their national publications into the international scientific network (Russell, 1995). The prolific countries' (top ten) authors who mostly contribute articles jointly with the authors from these four Indian universities are indicated in Table 7. Table 7 shows a fairly wide geographical distribution. It is interesting to see that, next to India, the United States ranks highest in collaboration with the authors from these four Indian universities. After that, the collaboration is more variable. For example, it is Germany for BHU and JNU, Saudi Arabia for AMU, and England for DU. Other prominent countries are Japan, the People's Republic of China, Canada, etc. The worldwide collaboration with authors from all these universities may be dependent upon the quality of research conducted in these universities and the authors' standing in the scholarly world. 
Table 7: Geographic Location of Collaborative Authors (Top Ten)

\begin{tabular}{|l|c|l|c|}
\hline Uttar Pradesh & Number of Articles & BHU & Number of Articles \\
\hline AMU & 1,691 & India & 3,206 \\
\hline India & 45 & USA & 220 \\
\hline USA & 41 & Germany & 198 \\
\hline Saudi Arabia & 34 & Japan & 123 \\
\hline Germany & 33 & France & 108 \\
\hline Taiwan & 20 & People's Rep. China & 86 \\
\hline Canada & 17 & South Korea & 84 \\
\hline England & 15 & Sweden & 80 \\
\hline Japan & 11 & Brazil & 78 \\
\hline Ethiopia & 11 & Hungary & 78 \\
\hline Malaysia & 9 & Taiwan & 76 \\
\hline Italy & \multicolumn{3}{|l|}{} \\
\hline Delhi & Number of Articles & JNU & Number of Articles \\
\hline DU & 3,972 & India & 1,407 \\
\hline India & 463 & USA & 151 \\
\hline USA & 223 & Germany & 53 \\
\hline England & 195 & Japan & 19 \\
\hline Germany & 156 & England & 14 \\
\hline People's Rep. China & 148 & Canada & 12 \\
\hline France & 146 & France & 10 \\
\hline Russia & 141 & Australia/Sweden & 8 \\
\hline South Korea & 140 & Israel & 6 \\
\hline Brazil & 134 & Netherlands & 6 \\
\hline Mexico & 127 & Scotland & 6 \\
\hline Colombia & & \multicolumn{2}{|l|}{} \\
\hline
\end{tabular}

\section{Institutes Prolific in Collaborative Research}

The top ten institutes whose authors collaborate on articles with the authors from these four universities are mentioned in Table 8. It is interesting to note that each Indian university collaborates with totally different institutes. Exceptions are the Indian Institute of Technology, Jamia Millia Islamia University, SUNY Stony Brook, and the Centre for Nuclear Science, all of which have authors who have collaborated with authors from each of the Indian universities targeted in this study. 
Table 8: Top Institutes

\begin{tabular}{|c|c|c|c|}
\hline \multicolumn{4}{|l|}{ Uttar Pradesh } \\
\hline AMU & No. & BHU & No. \\
\hline Jamia Millia Islamia, India & 68 & Indian Institute of Technology & 85 \\
\hline Indian Institute of Technology, India & 44 & Bhabha Atomic Research Centre & 80 \\
\hline National Sun Yat-sen University, Taiwan & 23 & University of Tokyo & 79 \\
\hline Nuclear Science Centre, New Delhi & 18 & Tokyo Institute Technology & 76 \\
\hline $\begin{array}{l}\text { King Fahd University Petroleum \& } \\
\text { Minerals, Saudi Arabia }\end{array}$ & 18 & University of Munster, Germany & 75 \\
\hline University of Hannover, Germany & 16 & Vanderbilt University, USA & 74 \\
\hline University of Jammu, India & 16 & Waseda University, Japan & 73 \\
\hline Central Drug Research Institute, India & 11 & Brookhaven National Laboratory, USA & 72 \\
\hline DSN College, Unnao, India & 9 & Oak Ridge National Laboratory, USA & 72 \\
\hline St Francis Xavier University, Canada & 8 & SUNY Stony Brook University, NY & 72 \\
\hline \multicolumn{4}{|l|}{ Delhi } \\
\hline DU & No. & JNU & No. \\
\hline Tata Institute of Fundamental Research & 146 & University of Delhi & 52 \\
\hline National Physical Laboratory & 142 & $\begin{array}{l}\text { International Centre for Genetic } \\
\text { Engineering \& Biotechnology }\end{array}$ & 34 \\
\hline Panjab University & 137 & Indian Institute of Technology & 31 \\
\hline Brookhaven National Laboratory, USA & 135 & Jamia Millia Islamia & 24 \\
\hline Michigan State University & 135 & National Control Plant Genome Research & 18 \\
\hline University of Rochester, USA & 132 & National Institute of Immunology & 17 \\
\hline Columbia University & 131 & $\begin{array}{l}\text { Gobind Ballav Pant Institute of } \\
\text { Himalayan Environment \& Development }\end{array}$ & 17 \\
\hline SUNY Stony Brook University, NY & 131 & All India Institute of Medical Science & 15 \\
\hline University of California Riverside, USA & 131 & Annamalai University & 14 \\
\hline University of Maryland, USA & 131 & Nuclear Science Centre, New Delhi & 14 \\
\hline
\end{tabular}

\section{Distribution to Periodicals}

Table 9 includes the list of the top ten periodicals that published most of the articles contributed by the authors from these universities. The periodicals are arranged in decreasing order by the number of articles published. The table shows that Current Science is one of the most preferred periodicals of Indian origin among the authors of three of the four universities. Other journals preferred by authors from at least two of the universities have also been noted. They are Contributions to Indian Sociology, Indian Journal of Chemistry Section A-Inorganic Bio-Inorganic Physical Theoretical \& Analytical Chemistry, Indian Journal of Chemistry Section B-Organic Chemistry Including Medicinal Chemistry, Journal of the Geological Society of India, Journal of the Indian Chemical Society, Microwave and Optical Technology Letters, Physical Review Letters, Spectrochimica Acta Part A-Molecular and Biomolecular Spectroscopy, and Synthesis and Reactivity in Inorganic and MetalOrganic Chemistry. It is interesting to observe that out of the top ten most preferred periodicals, authors from AMU mostly prefer to contribute their articles to journals of Indian origin whereas authors from JNU prefer periodicals of foreign origin. 
Table 9: Top Sources to which Authors Contributed Articles

\begin{tabular}{|c|c|c|c|}
\hline \multicolumn{4}{|l|}{ Uttar Pradesh } \\
\hline AMU & $\begin{array}{c}\text { No. of } \\
\text { articles }\end{array}$ & BHU & $\begin{array}{l}\text { No. of } \\
\text { articles }\end{array}$ \\
\hline $\begin{array}{l}\text { Indian Journal of Chemistry Section A- } \\
\text { Inorganic Bio-Inorganic Physical Theoretical E } \\
\text { Analytical Chemistry }\end{array}$ & 32 & Current Science & 116 \\
\hline Transition Metal Chemistry & 24 & $\begin{array}{l}\text { Materials Science and Engineering A- } \\
\text { Structural Materials Properties } \\
\text { Microstructure and Processing }\end{array}$ & 50 \\
\hline Journal of the Geological Society of India & 23 & Physical Review Letters & 47 \\
\hline $\begin{array}{l}\text { Colloids and Surfaces A-Physicochemical and } \\
\text { Engineering Aspects }\end{array}$ & 22 & $\begin{array}{l}\text { Microwave and Optical Technology } \\
\text { Letters }\end{array}$ & 44 \\
\hline $\begin{array}{l}\text { Synthesis and Reactivity In Inorganic and } \\
\text { Metal-Organic Chemistry }\end{array}$ & 22 & $\begin{array}{l}\text { Spectrochimica Acta Part A-Molecular } \\
\text { and Biomolecular Spectroscopy }\end{array}$ & 43 \\
\hline Indian Journal of Chemical Technology & 21 & Journal of the Geological Society of India & 39 \\
\hline $\begin{array}{l}\text { Indian Journal of Chemistry Section B-Organic } \\
\text { Chemistry Including Medicinal Chemistry }\end{array}$ & 19 & $\begin{array}{l}\text { Indian Journal of Chemistry Section A- } \\
\text { Inorganic Bio-Inorganic Physical } \\
\text { Theoretical \& Analytical Chemistry }\end{array}$ & 35 \\
\hline Journal of the Indian Chemical Society & 19 & Journal of Materials Science & 35 \\
\hline Bulletin of Electrochemistry & 18 & Pramana-Journal of Physics & 32 \\
\hline $\begin{array}{l}\text { Journal of Mathematical Analysis and } \\
\text { Applications }\end{array}$ & 18 & $\begin{array}{l}\text { Synthesis and Reactivity in Inorganic } \\
\text { and Metal-Organic Chemistry }\end{array}$ & 28 \\
\hline \multicolumn{4}{|l|}{ Delhi } \\
\hline DU & $\begin{array}{c}\text { No. of } \\
\text { articles }\end{array}$ & JNU & $\begin{array}{l}\text { No. of } \\
\text { articles }\end{array}$ \\
\hline Current Science & 107 & Current Science & 59 \\
\hline Physical Review D & 84 & $\begin{array}{l}\text { Biochemical and Biophysical Research } \\
\text { Communications }\end{array}$ & 55 \\
\hline Physical Review Letters & 66 & Physical Review E & 52 \\
\hline $\begin{array}{l}\text { Spectrochimica Acta Part A-Molecular and } \\
\text { Biomolecular Spectroscopy }\end{array}$ & 59 & Contributions to Indian Sociology & 28 \\
\hline Contributions to Indian Sociology & 53 & Journal of Biosciences & 20 \\
\hline $\begin{array}{l}\text { Indian Journal of Chemistry Section A- } \\
\text { Inorganic Bio-Inorganic Physical Theoretical E } \\
\text { Analytical Chemistry }\end{array}$ & 51 & Molecular and Cellular Biochemistry & 19 \\
\hline Microwave and Optical Technology Letters & 49 & Physical Review B & 18 \\
\hline Physics Letters B & 49 & Journal of Biological Chemistry & 13 \\
\hline $\begin{array}{l}\text { Indian Journal of Chemistry Section B-Organic } \\
\text { Chemistry Including Medicinal Chemistry }\end{array}$ & 48 & Journal of Chemical Physics & 12 \\
\hline Journal of the Indian Chemical Society & 43 & Journal of Physics-Condensed Matter & 12 \\
\hline
\end{tabular}

\section{Distribution of Papers According to Broad Subjects}

The departmental affiliations of the authors indicate the prominent research areas of these universities. The distribution of papers according to broad subject is presented in table 10. Table 10 principally lists the top ten broad subjects regarding which authors of these universities 
mostly contribute articles. From the data in Table 10 one can clearly infer that biochemistry and molecular biology are one of the most prolific research areas among these four universities. Other prolific fields of research are pharmacology and pharmacy, physics, plant science, biotechnology and applied microbiology, chemistry, electrical and electronic engineering and material science.

Table 10: Distribution of Papers According to Broad Subjects

\begin{tabular}{|l|c|l|l|}
\hline AMU & & BHU & \\
\hline Biochemistry \& Molecular Biology & 186 & Materials Science, Multidisciplinary & 313 \\
\hline Chemistry, Multidisciplinary & 137 & Biochemistry \& Molecular Biology & 194 \\
\hline Chemistry, Physical & 118 & Engineering, Electrical \& Electronic & 169 \\
\hline Mathematics, Applied & 111 & Multidisciplinary Sciences & 154 \\
\hline Engineering, Chemical & 77 & Physics, Applied & 154 \\
\hline Pharmacology \& Pharmacy & 70 & Chemistry, Physical & 148 \\
\hline Chemistry, Analytical & 67 & Physics, Multidisciplinary & 146 \\
\hline Chemistry, Inorganic \& Nuclear & 66 & Plant Sciences & 145 \\
\hline Biotechnology \& Applied Microbiology & 65 & Physics, Condensed Matter & 143 \\
\hline Mathematics/ Environmental Science & 62 & Pharmacology \& Pharmacy & 137 \\
\hline DU & & JNU & \\
\hline Biochemistry \& Molecular Biology & 314 & Biochemistry \& Molecular Biology & 239 \\
\hline Physics, Multidisciplinary & 252 & Biophysics & 101 \\
\hline Chemistry, Multidisciplinary & 250 & Physics, Mathematical & 77 \\
\hline Biotechnology \& Applied Microbiology & 235 & Multidisciplinary Sciences & 72 \\
\hline Plant Sciences & 228 & Cell Biology & 69 \\
\hline Physics, Applied & 222 & Physics, Condensed Matter & 68 \\
\hline Chemistry, Organic & 212 & Environmental Sciences & 66 \\
\hline Materials Science, Multidisciplinary & 191 & Plant Sciences & 65 \\
\hline Engineering, Electrical \& Electronic & 189 & Pharmacology \& Pharmacy & 55 \\
\hline Physics, Condensed Matter & 187 & Physics, Fluids \& Plasmas & 53 \\
\hline
\end{tabular}

\section{Prolific Authors}

Table 11 documents the top fifteen most published authors during 2000-2007 from these four universities as indexed in Web of Science. The credit for the most productive author goes to R.K. Shivpuri, Department of Physics, Delhi University, followed by Virinder S. Parmar, Department of Biochemistry, Delhi University, and O.N. Srivastava, Department of Physics, Banaras Hindu University. Interestingly, however, the author with the highest number of citations received is N.N. Ajitanand, Department of Physics, Banaras Hindu University, followed by Vivek Singh, Department of Physics, Banaras Hindu University. These counts are, of course, limited to pieces published in archival journals covered by the indexes; books, monographs, technical reports, and other non-archival products are not included in these counts. It is equally essential to note that almost all the publications of these authors were reported with joint rather than single authorship. 
Table 11: Prolific Authors

\begin{tabular}{|l|c|c|c|}
\hline Author & $\begin{array}{c}\text { Number of } \\
\text { Articles }\end{array}$ & $\begin{array}{c}\text { No. of } \\
\text { References } \\
\text { Given }\end{array}$ & $\begin{array}{c}\text { No. of } \\
\text { Citations } \\
\text { Received }\end{array}$ \\
\hline Shivpuri, R.K., Dept. Physics, Delhi University & 142 & 4,663 & 1,264 \\
\hline Parmar, Virinder S, Dept. Biochemistry, Delhi University & 127 & 3,554 & 544 \\
\hline Srivastava, O.N., Dept. Physics, Banaras Hindu University & 104 & 2,303 & 350 \\
\hline $\begin{array}{l}\text { Kabir-Ud-Din, Dept. Chemistry, Aligarh Muslim } \\
\text { University }\end{array}$ & 95 & 3,506 & 293 \\
\hline $\begin{array}{l}\text { Sundar, S., Dept. of Medicine, Institute of Medical Science, } \\
\text { Banaras Hindu University }\end{array}$ & 88 & 2,877 & 1,246 \\
\hline $\begin{array}{l}\text { Quraishi, Mumtaz Ahmad, Faculty of Engineering \& } \\
\text { Technology, Dept. Applied Chemistry, Aligarh Muslim } \\
\text { University }\end{array}$ & 73 & 1,333 & 234 \\
\hline Singh, Vivek, Dept. Physics, Banaras Hindu University & 64 & 2,496 & 3,196 \\
\hline Ajitanand, N.N, Dept. Phys, Banaras Hindu University & 63 & 2,534 & 3,315 \\
\hline $\begin{array}{l}\text { Khan, Rizwan Hasan, Interdisciplinary Biotechnology } \\
\text { Unit, Aligarh Muslim University }\end{array}$ & 57 & 2,332 & 272 \\
\hline $\begin{array}{l}\text { Khan, Mukhtar A, Dept. Zoology, Fish Nutrition Research } \\
\text { Laboratory, Aligarh Muslim University }\end{array}$ & 56 & 1,951 & 145 \\
\hline $\begin{array}{l}\text { Prasad, Rajendra School of Life Science, Jawaharlal Nehru } \\
\text { University }\end{array}$ & 47 & 2,024 & 333 \\
\hline $\begin{array}{l}\text { Ramaswamy, R., School of Physical Science, Jawaharlal } \\
\text { Nehru University }\end{array}$ & 45 & 1,405 & 168 \\
\hline $\begin{array}{l}\text { Ghosh, Subhasis, School of Physical Science, Jawaharlal } \\
\text { Nehru University }\end{array}$ & 42 & 1,143 & 181 \\
\hline $\begin{array}{l}\text { Puri, Sanjay, School of Physical Science, Jawaharlal Nehru } \\
\text { University }\end{array}$ & 41 & 1,676 & 182 \\
\hline $\begin{array}{l}\text { Bhattacharya, Alok, School of Life Science, Jawaharlal } \\
\text { Nehru University }\end{array}$ & 40 & 1,213 & 356 \\
\hline
\end{tabular}

\section{Citations Given Versus Citations Received}

Table 12 shows the data for the 10,281 items published by authors of these four universities contained 288,029 references and received 34,282 citations during 2000-2007. The average number of references per item was 28 , and the average number of citations received per item was 3.56. The growth rate of references per items has tended to increase over the period 20002007, whereas the number of citations received has decreased during the same period. The average rate of references per item during 2000-2007 varied from a minimum of 23.71 (AMU), 24.48 (BHU), 22.68 (DU) and 27.69 (JNU) to a maximum of 31.63 (AMU), 31.51 (BHU), 33.44 (DU) and 35.49 (JNU). The rate of citations received per item during 2000-2007 varied from a minimum of 0.18 (AMU), 0.28 (BHU), 0.23 (DU) and 0.26 (JNU) to a maximum of 6.69 (AMU), 7.81 (BHU), 5.98 (DU) and 7.15 (JNU). The highest number of references per item was noted in 2007 for all these universities. However, articles for 2000 from AMU (6.69) and DU (5.98), for 
2002 from BHU (7.81), and 2001 from JNU (7.15) received the highest number of citations per item. Overall, articles from DU contained the highest number of references $(109,311)$ during 2000-2007, and articles from BHU received the highest percentage of citations (i.e., 4.21 citations per item).

Table 12: Distribution of Citations Given and Citations Received

\begin{tabular}{|c|c|c|c|c|c|c|c|c|c|c|c|c|c|c|c|c|}
\hline \multirow[t]{2}{*}{ Year } & \multicolumn{4}{|c|}{ AMU } & \multicolumn{4}{|c|}{ BHU } & \multicolumn{4}{|c|}{ DU } & \multicolumn{4}{|c|}{ JNU } \\
\hline & CG & RA & CR & CA & CG & RA & CR & CA & CG & RA & CR & CA & CG & RA & CR & CA \\
\hline 2007 & 8,669 & 31.63 & 30 & 0.10 & 16,956 & 31.51 & 151 & 0.28 & 20,299 & 33.44 & 141 & 0.23 & 5,927 & 35.49 & 44 & 0.26 \\
\hline 2006 & \begin{tabular}{|l|l|}
8,737 \\
\end{tabular} & 29.62 & 172 & \begin{tabular}{|l|}
0.58 \\
\end{tabular} & 13,559 & 28.19 & 633 & 1.32 & 17,144 & 27.83 & 763 & 1.24 & 5,900 & 30.57 & 159 & 0.82 \\
\hline 2005 & 7,358 & 28.41 & 381 & 1.47 & 11,504 & 30.19 & 1,214 & 3.19 & 16,005 & 27.45 & 1,723 & 2.96 & 6,518 & 30.18 & 561 & 2.60 \\
\hline 2004 & 5,980 & 28.08 & 566 & 2.66 & 10,133 & 27.54 & 1,437 & 3.90 & 13,068 & 25.72 & 1,644 & 3.24 & 6,844 & 35.46 & 618 & 3.20 \\
\hline 2003 & 5,362 & 25.29 & 748 & 3.53 & 8,937 & 24.48 & 1,902 & 5.21 & 14,653 & 29.31 & 2,290 & 4.58 & 4,812 & 28.64 & 589 & 3.51 \\
\hline 2002 & 3,867 & 25.27 & 535 & 3.50 & 8,321 & 25.84 & 2,514 & 7.81 & 10,575 & 25.67 & \begin{tabular}{|l|}
2,359 \\
\end{tabular} & 5.73 & 4,514 & 27.69 & 675 & 4.14 \\
\hline 2001 & 3,693 & 25.12 & 712 & 4.84 & 9,220 & 25.61 & 2,257 & 6.27 & 10,308 & 24.03 & 2,399 & 5.59 & 4,901 & 27.69 & 1,265 & 7.15 \\
\hline 2000 & 3,248 & 23.71 & 917 & 6.69 & 10,116 & 25.87 & 2,215 & 5.66 & 7,259 & 22.68 & 1,914 & 5.98 & 3,642 & 27.80 & 754 & 5.76 \\
\hline & 46,914 & 27.14 & 4061 & 2.92 & 88,746 & 27.4 & 12,323 & 4.21 & 109,311 & 27.02 & 13,233 & 3.69 & 43,058 & 30.44 & 4,665 & 3.43 \\
\hline
\end{tabular}

CG: Citations Given, CR: Citations Received, RA: Average References per article, CA: Average Citation Received per article.

\section{Conclusion}

Kaushik Basu, professor of economics, Cornell University, in his article posted on BBC Online (2006), pointed out India's faltering higher education system. According to Basu:

India's production of professionals is phenomenal. With over 300 universities and 15,600 colleges spewing out 2.5 million graduates each year, in terms of the volume of production India trails behind only the US and recently China .... In terms of research and the purely academic disciplines, such as mathematics, physics and literature, India is beginning to trail in comparison not just to other countries but its own past performance. (2006, np).

In fact, after independence, India had to respond to many problems, and funding for science and research was not a high priority until the recent period of economic boom. Still, in India, no standard evaluation method exists for measuring the quality of scientific productivity in universities. The newly developed National Assessment \& Accreditation Council (NAAC) recently measured the performance of some Indian universities, grading them on a five-point scale. With the exception of BHU, none of the universities in this study is currently accredited by NAAC. The results of the present study, however, suggest that the quantity of research output from these central government universities is quite satisfactory. Although the number of faculty at each institution has influenced publication rates, these four universities with similar missions can be cautiously compared to each other regarding faculty publication productivity.

The data in the present study suggest that the science faculties (mostly applied science) of these four universities are quite productive in publications (most appearing in peer-reviewed Indian journals) as compared to social sciences and arts and humanities faculty. The present pilot study includes only four prestigious universities of India. The picture, however, may be more vivid if one can compare the research productivity of Indian Institutes of Management and Indian Institutes of Technology with that of academic institutions. 
It is quite evident that the library facilities, technological infrastructure, and research funds that are basic prerequisites for conducting quality research are uneven in Indian universities. Although budget allocations are quite healthy in central universities as compared to stateowned universities, the attitude of the researcher is also essential for better research. In addition, to attract some of the best minds to fundamental research, we have to award research funding to match a scholar's productivity.

\section{References}

Abrahamson, E. (1991). Managerial fad and fashion: The diffusion and rejection of innovations. Academy of Management Review, 16(3), 586-612.

Abrahamson, E. (1996). Managerial fashion. Academy of Management Review, 21(1), 254-285.

Abrahamson, E., \& Fairchild, S., (1999). Management fashion: Lifecycles, triggers and the collective learning processes. Administrative Science Quarterly, 44, 708-740.

Basu, K. (2006). India's faltering education system. Retrieved December 29, 2007, from http://news.bbc.co.uk/2/hi/south_asia/4793311.stm

Harsanyi, M. A. (1993). Multiple authors, multiple problems - Bibliometrics and the study of scholarly collaboration: A literature review. Library and Information Science Research, 15(Fall), 325-54.

Nye, J. S., \& Keohane, R. O., (1972). Introduction. In R. O. Keohane \& J. S. Nye (Eds.). Transnational relations and world politics. Cambridge, MA: Harvard University Press.

Ponzi, J., \& Koenig, M., (2003). Knowledge management: Another management fad. Retrieved December 1, 2007, from http://pages.globetrotter.net/charro/HERMES9/ponzi_koenig.htm

Qiu, L. (1992). A study of interdisciplinary research collaboration. Research Evaluation, 2(3), 16975.

Russell, M. (1995). The increasing role of international cooperation in science and technology research in Mexico. Scientometrics, 34(1), 45-61.

Subramanyam, K. (1983). Bibliometric studies of research collaboration: A review. Journal of Information Science, 6(1), 33-38.

Van Raan, A. (1998). The influence of international collaboration on the impact of research results. Scientometrics, 42(3), 423-428.

Van Raan, A. (1999). Advanced bibliometric methods for the evaluation of universities. Scientometrics, 45(3), 417-423.

\section{Suggested Reading}


Braun, T. (1999). Bibliometric indicators for the evaluation of universities - Intelligence from the quantitation of the scientific literature. Scientometrics, 45(3), 425-432.

Gomez, B. J., Hidalgo, M., Guilera, F. G., \& Moreno, T. M. (2005). Bibliometric study of differential item functioning. Scientometrics, 64(1), 3-16.

Korytnyk, C. A. (1988). Comparison of the publishing patterns between men and women Ph.D.s in Librarianship. Library Quarterly, 58(1), 52-65.

Law, R., \& Chon, K. (2007). Evaluating research performance in tourism and hospitality: The perspective of university program heads. Tourism Management, 28(5), 1203-1211.

Maani, K. E. (1989). Productivity and profitability through quality - Myth and reality. International Journal of Quality \& Reliability Management, 6(3).

DOI: $10.1108 / 02656718910134421$

Muula, A. S. (2007). Status of scholarly productivity among nursing academics in Malawi. Croatian Medical Journal, 48(4), 568-573.

\section{Acknowledgement}

The author would like to acknowledge the anonymous referees and the editor for their valuable suggestions. 